\title{
Optimization test of operation of URB/ZS-3 automatic machine for breaking oversized lumps under conditions of Polkowice-Sieroszowice mine
}

\begin{abstract}
This article presents the experience from the first stage of the optimization tests of an automatic machine for breaking oversized lumps. The tests took place between December 2017 and March 2018 at the O/ZG Polkowice-Sieroszowice mine. The URB/ZS-3 automatic machine was developed as part of the second competition of a joint venture financed by NCBR and KGHM Polska Miedź S.A. under the name of CuBR. The adopted methodology of carrying out the operational tests of the URB/ZS-3 machine was discussed, which had to take into account the specific requirements and operating conditions of the mining department in the Polkowice-Sieroszowice mine. The reference point for evaluating the effectiveness of the new solution was the cleaning times of the grate by a machine working in remote mode. The results of clearing the grate of excavated materials by a machine working in automatic mode were presented for various algorithms and scenarios included in the control software. The influence of the degree of ore fragmentation (including the number of oversized lumps) on the time of the grate cleaning was taken into account. The influence of the changes introduced in this software on the obtained grate discharge times was initially evaluated. The article also presents the impact of loading the grate with the use of loaders and haul trucks on the effectiveness of the automatic machine for breaking oversized lumps. Also, the driver elements of the machine were assessed in terms of their reliability, and the directions for possible structural changes were proposed. In conclusion, the directions for further activities aimed at optimizing the machine and increasing its efficiency and reliability were proposed.
\end{abstract}

Key words: optimization, mining, breaking oversized lumps

\section{INTRODUCTION}

The tests of the URB/ZS-3 automatic lump breaker under the conditions of the Polkowice-Sieroszowice mine took place as part of the research and development work carried out as a portion of the CuBR II project entitled "Type URB/ZS-3 automatic rock crushing machine for underground copper mines "-" co-financed by the National Center for Research and Development and KGHM Polska Miedź S.A. The project is carried out in a consortium whose members are KGHM ZANAM S.A., KGHM CUPRUM Sp. z o.o. CB-R, and AGH University of Science and Technology.

Prior to the in-house testing, a methodology was developed to determine the criteria necessary to be analyzed in order to assess the correct operation of the lump breaker as well as the performance of the automatic control system. 
A prototype of the machine was installed on a discharge point in the Polkowice-Sieroszowice mine in drift T-210/crut P-13 with an R-120/1 discharge grate onto a Legmet L-120 conveyor. The discharge point was subjected to optimization tests with excavation materials during the period of December 2017 to March 2018.

During the measurements, the times when the machine cleared the grate of oversized material were recorded, and the effectiveness of its operation was evaluated. The mechanical solutions of the automatic lump breaker and control software were also evaluated.

\section{URB/ZS-3 AUTOMATIC LUMP BREAKER}

The prototype of the URB/ZS-3 lump breaker was developed in response to the growing needs of KGHM Polska Miedź SA in connection with the need to increase the level of automation during the excavation of copper ore [1]. These needs result from the deteriorating mining conditions - increased air temperature, humidity, and the risk of bumps [2].

In addition, the automation of the process of breaking lumps would enable the optimization of the URB operators' working time and, thus, reduce the costs of copper ore excavation. In order to achieve these objectives, the machine must ensure that the grate is cleaned without intervention from the operator who would perform a control role and would get involved in the cleaning process remotely in specific cases [2].

The attempt to automate the process of crushing lumps was based on the existing equipment for breaking lumps (URB, manufactured by KGHM ZANAM), which was dictated by the need for an optimal conversion (from the point of view of the costs) from the currently applicable system of breaking oversized lumps (manual breaking with the operator directly on the grate and remote breaking) into a system operating in the automatic cycle [1].

The operation of the URB/ZS-3 is based on scanning the grate with a laser scanner that determines the commencement of the process of grate cleaning by assessing the degree of occupancy of the grate with excavated material. Coordination between the boommounted hammer, scanner, and control program are achieved by installing sensors and positioning angle and distance transducers [1].

\section{LOCATION}

The prototype of the URB/ZS-3 automatic lump breaker was installed on the discharge point in the Polkowice-Sieroszowice mine in drift T-210/crut P 13 with an R-120/1 discharge grate onto an Legmet L-120 conveyor. The installation of the machine is shown in Figure 1, and a diagram of the discharge point is shown in Figure 2.

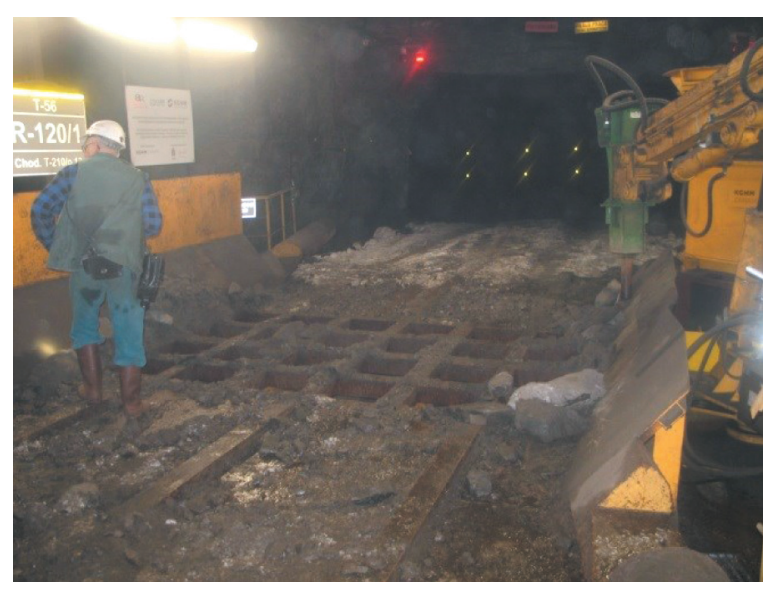

Fig. 1. Method of installation of URB/ZS-3 in Polkowice-Sieroszowice mine

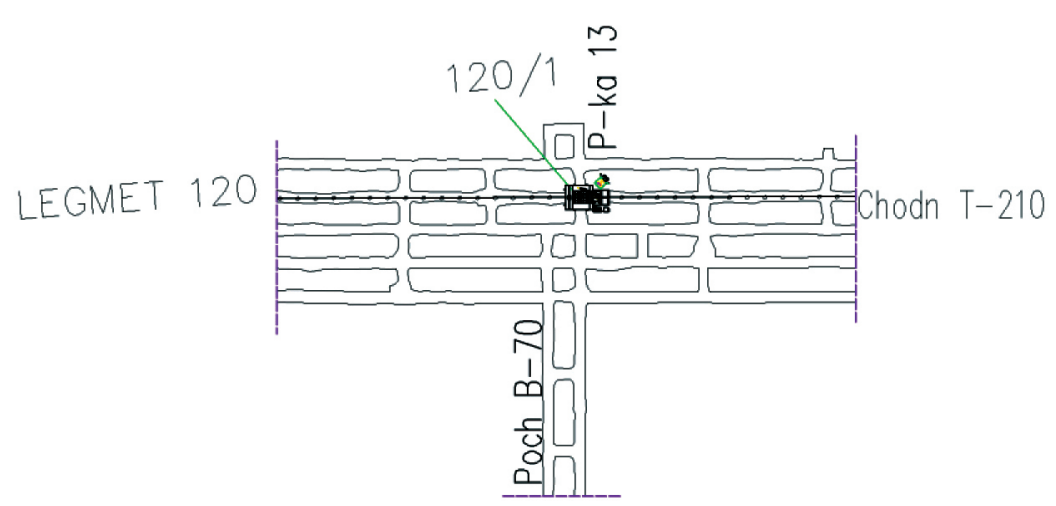

Fig. 2. Location of URB/ZS-3 in Polkowice-Sieroszowice mine 
At the same time, the URB/ZS-3 control station equipped with a remote-control console and control cabinets enabling remote work on the grate were installed in the SK-2 control room on the shaft bottom of the SW-1 shaft. The method of installation in the control room is shown in Figure 3.

The control room has access to the monitoring of the R120/1 grate, allowing for control of the entrance signaling (thanks to which, it is possible to cooperate with an operator of a haul truck).

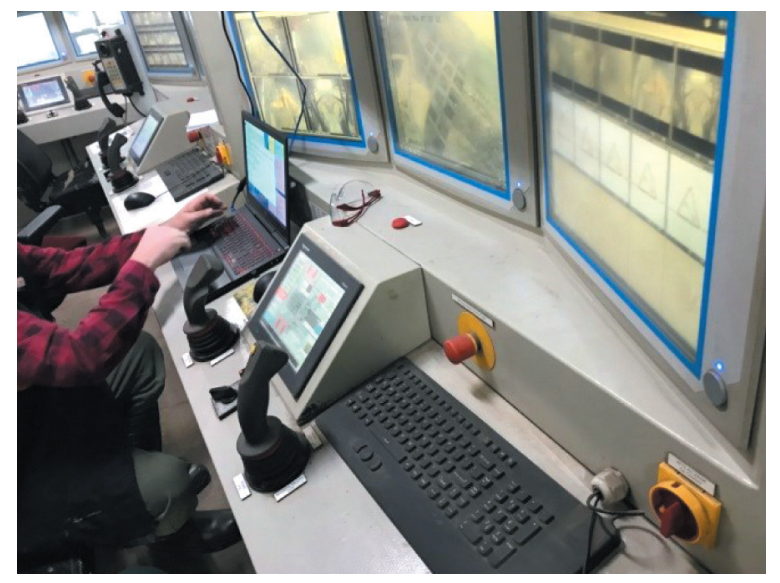

Fig. 3. Remote control console in SK-2 control room on shaft bottom of $S W-1$ shaft

\section{ASSESSMENT CRITERIA}

The tests were preceded by the preparation of the appropriate rules for assessing the correctness of the operation of the URB/ZS-3 automatic lump breaker. The correctness of the operation of the machine itself and the operation of the control algorithm were assessed.

The basic parameters for determining the working capability of the lump breaking machine are as follows [2]:

- correct operation of the hydraulic system of the boom with an impact hammer,

- no leaks in the hydraulic system,

- correct settings of the safety valve,

- correct operation of the automatic lubrication system,

- correct operation of the laser scanner,

- correct operation of the drawer-like feeder system,

- possible taking over of remote control of the machine from the SK-2 control room on the shaft bottom of the SW-1 shaft.
The basic parameters to be checked during the operation of the control algorithm are as follows [1]:

- the duration of the self-cleaning cycle of the discharge grate,

- the degree of cleaning the grate after the end of the operating cycle,

- the impact of the type of excavation material (degree of fragmentation, dampness, etc.) on the duration of the self-cleaning cycle of the discharge grate,

- the effect of the type of excavated material on the degree of cleaning the grate at the end of the machine cycle,

- the correctness of the assessment of the distribution of excavated material on the discharge grate by the laser scanner,

- the ability of the machine to search for excavated material and skip the empty areas of the discharge grate,

- the ability of the machine to search for and break down oversized lumps,

- the ability of the machine to search for and rake fine excavated material,

- the correctness of the operation of the entry gates that automatically turn on the machine.

\section{OPTIMIZATION TESTS}

Five optimizing bottom tests were carried out to improve the algorithm's performance in terms of the efficiency and speed of the grate cleaning. The tests were carried out with the use of LKP-0903 bucket loaders manufactured by KGHM ZANAM, each with a load capacity of approx. $7 \mathrm{Mg}$ of excavated material. The planned optimization works with the WO CB4 haul trucks (each with a capacity of $20 \mathrm{Mg}$ of excavated material) were carried out on a partial basis due to the failure of the machine in March 2018.

The material used in the tests covered the full range of grain found in the mines of KGHM Polska Miedź S.A. The aim was to adapt the algorithm to the changing conditions on the discharge grate depending on the type of excavated material, location of the mining unit, and general variability of the grain size resulting from the application of the method of mining faces with explosives in a room-and-pillar mining system. 
The tests were aimed at developing the appropriate parameters and settings in the control algorithms, improving the operating time of the URB/ZS-3 and ensuring the appropriate ratio of the duration of the cleaning cycle to the level of clearing the grate of excavated material [1].

The optimization tests were based on the definition of the necessary modifications to the software and on the determination of an acceptable grate occupancy level in order to maintain the continuity of haulage, which allows machines to pass through the grate if necessary [1].

An example of a grate before cleaning is shown in Figure 4. About $7 \mathrm{Mg}$ of excavated material with fine characteristics was delivered to the grate. Figure 5 shows the grate after cleaning with the URB/ZS-3 automatic lump breaker. The degree of clearing the grate was considered satisfactory.

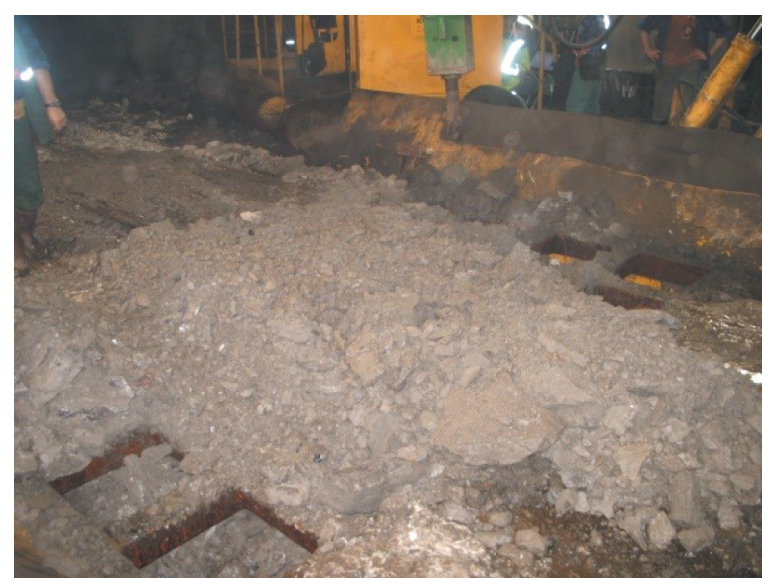

Fig. 4. Grate after LKP-0903 loader has unloaded excavated material

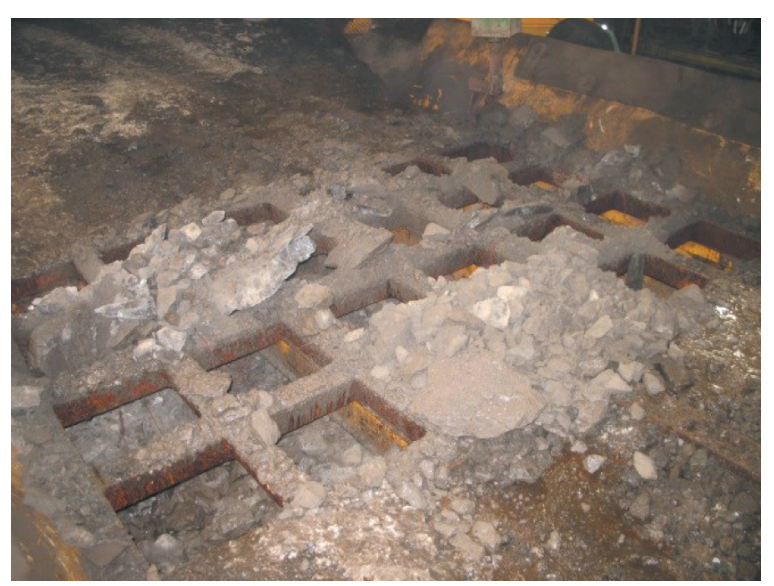

Fig. 5. Grate after URB/ZS-3 has automatically cleaned it
As a result of the optimization tests, three modes of operation were introduced to the cleaning algorithm:

- the breaking of lumps in the meshes of the grate (chiseling mode),

- the raking of excavated material on the grate (spreading mode),

- the breaking of lumps at their geometric centers determined by scanning ("single" mode).

After the optimization process, the cleaning modes were significantly simplified in order to shorten the cleaning program time. In the initial phase of the tests, the chiseling mode consisted of the preliminary raking of excavated material from the mesh bars of the grate and then breaking a lump in the middle of the mesh of the grate. As a part of the tests, the program has been simplified; in its current version, it consists in the hammer running over the geometric center of the grate mesh. The machine is then lowered, and the impactor in the hydraulic hammer is activated as soon as the resistance of a lump is encountered.

The raking mode has been simplified to angular runs in place of the initial run along the grid bars. This significantly speeds up the cleaning of the grate from fine excavated material when compared to the previous solution.

The "single" mode was introduced in a late stage of the tests. It is used to break up lumps in the last phase of the algorithm's operation after the execution of the raking and spreading modes.

The modes are arranged in scenarios depending on the type of excavator (haul truck/bucket loader) and the degree of occupancy of the grate.

The occupancy rate of the grate was determined on the basis of the scanning performed before and during the implementation of the cleaning scenario. The lump breaker should continue the cleaning process until the set value is reached, after which it should allow the next machine to enter the plant after reaching the set parameter. The optimization tests resulted in a satisfactory limit value of $17 \%$ occupancy of the grate. The height of the excavated material (which allows free passage of the machine) was determined at $150 \mathrm{~mm}$ above the grate as a result of the optimization tests.

When the excavated material is unloaded onto the grate, the control system reads the occupancy rate 
and activates the URB/ZS-3 when the supplied excavated material fills the grate to more than $17 \%$ of the occupancy rate. The cleaning work continues until the occupancy rate is below $17 \%$.

During the measurements, the duration of the individual cycles from the moment of switching on the automatic self-cleaning mode to the return of the URB hydraulic hammer to its base point was recorded, and the efficiency and degree of the cleaning of the grate after each measurement was determined. Additionally, in order to ensure the best possible reproduction of the operating conditions, $15 \mathrm{~s}$ before the URB/ZS-3 start-up, the R-120/1 drawer-like grate feeder was switched on, which enabled the fine excavated material to be pre-poured - grate self-cleaning.

During normal operation, it is planned to ensure control of the movement of the dumping machines in the area of the grate by the URB/ZS-3 system. This is achieved by controlling the traffic light, which draws information (among other things) from special gates installed at the entrances to the grate. During the optimization tests, the operator's entry signaling was not tested. The green light and permission to enter the grate were given by the supervising operator from the SK-2 control room [2].

The times of the individual measurements and results of the tests are presented in Table 1 for the optimization tests and Table 2 for the algorithm-verification tests. The grate was considered cleaned if, after the completion of a test, the state of the occupation of the grate made it possible to reload excavated material.

The URB/ZS-3 optimization tests were carried out at 5 mining shifts, during which 39 measurements were made using approx. $280 \mathrm{Mg}$ of excavated material (40 buckets of the LKP-0903 loader), of which 8 ended with the cleaning of the grate. The mean duration of a positive test from the moment of activation to the moment of deactivation of the URB/ZS-3 was126 s.

The tests verifying the URB/ZS-3 were carried out at three working shifts; however, due to the failure of the machine during the first tests with haul trucks on the second day of the tests, it was necessary to discontinue the tests.

Eleven measurements were made during the first shift, using approx. $105 \mathrm{Mg}$ of excavated material (15 buckets of the LKP-0903 loader), of which nine ended with the cleaning of the grate. The mean duration of a positive test from the moment of activation to the moment of deactivation of the URB/ZS-3 was $293 \mathrm{~s}$.
During the tests on March 15, 2018, the machine malfunctioned. The fastening of the piston rod position sensor of the swivel actuator of the URB/ZS-3 was damaged, causing the machine to decalibrate and the hydraulic hammer to lose its zero point. Due to the design of the measuring system (a sensor installed in the piston rod), the entire swivel actuator had to be replaced. After the analysis, it was found that the failure of the piston rod position sensor fastening in the rotary actuator occurred as a result of the incorrect sensor securing in the fastening socket. Polyurethane resin was used, which was ultimately destroyed by the temperature of the working medium. The unprotected sensor under the influence of impact work of the URB/ZS-3 started to move, which caused the machine's decalibration.

Since the distance sensors are installed in all four actuators of the lump breaking machine, consideration should be given to changing the adopted concept of securing the sensor and recording the piston rod extension.

The failure made it impossible to carry out full haulage tests with the CB4 haul trucks and optimize the algorithm accordingly. The optimization tests with a haul truck were carried out in parallel to the repairs of the decalibrated URB/ZS-3.

Table 3 shows the general results for the tests carried out at the discharge point using the URB/ZS-3 automatic lump breaker. The optimization tests were conducted on eight mining shifts from December 2017 to March 2018. A total of 55 tests were carried out, of which 21 ended with the cleaning of the grate, which results in a $38 \%$ efficiency. The average cleaning time was 4.8 minutes. Fifty tests were carried out with the use of a bucket loader, of which 17 were completed with the cleaning of the grate. The average cleaning time was 3.4 minutes. The table also includes statistics for the tests using a haul truck. Five tests were carried out, four of which ended with the cleaning of the grate. The average cleaning time was 10.7 minutes.

It should be noted that the tests conducted during the optimization period were of a research and verification nature. There were interruptions during the measurements and changes in the algorithm parameters. Hence, a low level of success of the tests and low shift use of the URB/ZS-3 were observed. The optimization of the software was additionally hampered by the changing nature of the excavation material - finer material requires a higher share of the raking mode than material with a higher share of oversized lumps. 
Table 1

Results of optimization tests of URB/ZS-3 automatic lump breaker

\begin{tabular}{|c|c|c|c|c|c|c|c|c|}
\hline \multirow{2}{*}{ Date of tests } & \multirow{2}{*}{$\begin{array}{l}\text { Number } \\
\text { of tests }\end{array}$} & \multirow{2}{*}{$\begin{array}{c}\text { Number of } \\
\text { positive tests }\end{array}$} & \multirow{2}{*}{$\begin{array}{l}\text { Additional } \\
\text { information }\end{array}$} & \multicolumn{2}{|c|}{ Excavated material } & \multirow{2}{*}{$\begin{array}{l}\text { Operating } \\
\text { time } \\
\text { duration of } \\
\text { URB [min] }\end{array}$} & \multirow{2}{*}{\multicolumn{2}{|c|}{ Positive test }} \\
\hline & & & & $\begin{array}{c}\text { loader } \\
\text { [bucket] }\end{array}$ & $\begin{array}{c}\text { truck } \\
\text { [truck] }\end{array}$ & & & \\
\hline \multirow{4}{*}{$\begin{array}{l}\text { December 19, } \\
2017\end{array}$} & \multirow{4}{*}{4} & \multirow{4}{*}{1} & \multirow{4}{*}{ optimization tests } & 3 & 0 & 5.0 & no & 0 \\
\hline & & & & 1 & 0 & 8.0 & no & 0 \\
\hline & & & & 1 & 0 & 4.0 & yes & 1 \\
\hline & & & & 3 & 0 & 8.0 & no & 0 \\
\hline \multirow{2}{*}{$\begin{array}{l}\text { January } 12, \\
2018\end{array}$} & \multirow{2}{*}{2} & \multirow{2}{*}{0} & \multirow{2}{*}{ optimization tests } & 5 & 0 & no test & no & 0 \\
\hline & & & & 4 & 0 & no test & no & 0 \\
\hline \multirow{8}{*}{$\begin{array}{l}\text { January } 31, \\
2018\end{array}$} & \multirow{8}{*}{8} & \multirow{8}{*}{6} & \multirow{8}{*}{ optimization tests } & 2 & 0 & 1.5 & yes & 1 \\
\hline & & & & 1 & 0 & 1.7 & yes & 1 \\
\hline & & & & 1 & 0 & 1.5 & yes & 1 \\
\hline & & & & 1 & 0 & 1.8 & yes & 1 \\
\hline & & & & 1 & 0 & 1.7 & yes & 1 \\
\hline & & & & 1 & 0 & 3.5 & no & 0 \\
\hline & & & & 3 & 0 & 3.0 & yes & 1 \\
\hline & & & & 3 & 0 & 2.8 & no & 0 \\
\hline \multirow{17}{*}{$\begin{array}{l}\text { February 2, } \\
2018\end{array}$} & \multirow{17}{*}{17} & \multirow{17}{*}{1} & \multirow{17}{*}{ optimization tests } & 1 & 0 & 1.7 & no & 0 \\
\hline & & & & prev. test & 0 & 1.7 & yes & 1 \\
\hline & & & & 1 & 0 & 1.7 & no & 0 \\
\hline & & & & prev. test & 0 & 2.8 & no & 0 \\
\hline & & & & 1 & 0 & 1.5 & no & 0 \\
\hline & & & & 1 & 0 & 3.3 & no & 0 \\
\hline & & & & prev. test & 0 & 3.8 & no & 0 \\
\hline & & & & prev. test & 0 & 3.7 & no & 0 \\
\hline & & & & 1 & 0 & 3.0 & no & 0 \\
\hline & & & & prev. test & 0 & 5.5 & no & 0 \\
\hline & & & & prev. test & 0 & 2.0 & no & 0 \\
\hline & & & & prev. test & 0 & 1.0 & no & 0 \\
\hline & & & & prev. test & 0 & 6.3 & no & 0 \\
\hline & & & & prev. test & 0 & 2.5 & no & 0 \\
\hline & & & & prev. test & 0 & 1.3 & no & 0 \\
\hline & & & & prev. test & 0 & 0.8 & no & 0 \\
\hline & & & & 1 & 0 & 2.0 & no & 0 \\
\hline \multirow{8}{*}{$\begin{array}{l}\text { February 28, } \\
2018\end{array}$} & & & & 1 & 0 & 1.0 & no & 0 \\
\hline & & & & prev. test & 0 & 7.0 & no & 0 \\
\hline & & & & prev. test & 0 & 6.0 & no & 0 \\
\hline & 8 & 0 & optimization tests & 1 & 0 & 3.0 & no & 0 \\
\hline & & & & 1 & 0 & 3.9 & no & 0 \\
\hline & & & & prev. test & 0 & 3.1 & no & 0 \\
\hline & & & & 1 & 0 & 7.0 & no & 0 \\
\hline & & & & prev. test & 0 & 1.5 & no & 0 \\
\hline
\end{tabular}


Table 2

Results of verification tests of URB/ZS-3 automatic lump breaker

\begin{tabular}{|c|c|c|c|c|c|c|c|c|}
\hline \multirow[b]{2}{*}{ Date of tests } & \multirow[b]{2}{*}{$\begin{array}{c}\text { Number of } \\
\text { tests }\end{array}$} & \multirow{2}{*}{$\begin{array}{c}\text { Number of } \\
\text { positive tests }\end{array}$} & \multirow[b]{2}{*}{$\begin{array}{l}\text { Additional } \\
\text { information }\end{array}$} & \multicolumn{2}{|c|}{ Excavated material } & \multirow{2}{*}{$\begin{array}{l}\text { Operating } \\
\text { time } \\
\text { duration of } \\
\text { URB [min] }\end{array}$} & \multirow{2}{*}{\multicolumn{2}{|c|}{ Positive test }} \\
\hline & & & & $\begin{array}{c}\text { loader } \\
\text { [bucket] }\end{array}$ & $\begin{array}{c}\text { truck } \\
\text { [truck] }\end{array}$ & & & \\
\hline \multirow{11}{*}{ March 9, 2018} & \multirow{11}{*}{11} & \multirow{11}{*}{9} & \multirow{11}{*}{$\begin{array}{l}\text { tests } \\
\text { testing algorithm }\end{array}$} & 3 & 0 & 6.0 & yes & 1 \\
\hline & & & & 1 & 0 & 4.0 & yes & 1 \\
\hline & & & & 1 & 0 & 11.0 & no & 0 \\
\hline & & & & 1 & 0 & 6.5 & no & 0 \\
\hline & & & & 1 & 0 & 10.7 & yes & 1 \\
\hline & & & & 2 & 0 & 4.0 & yes & 1 \\
\hline & & & & 2 & 0 & 3.0 & yes & 1 \\
\hline & & & & 1 & 0 & 4.0 & yes & 1 \\
\hline & & & & 1 & 0 & 4.3 & yes & 1 \\
\hline & & & & 1 & 0 & 3.3 & yes & 1 \\
\hline & & & & 1 & 0 & 1.5 & yes & 1 \\
\hline \multirow{2}{*}{ March 15, 2018} & \multirow{2}{*}{2} & \multirow{2}{*}{1} & \multirow{2}{*}{$\begin{array}{c}\text { machine } \\
\text { malfunction }\end{array}$} & 0 & 1 & 14.7 & yes & 1 \\
\hline & & & & 0 & 1 & 8.0 & no & 0 \\
\hline \multirow{3}{*}{ March 16, 2018} & \multirow{3}{*}{3} & \multirow{3}{*}{3} & \multirow{3}{*}{$\begin{array}{l}\text { machine } \\
\text { malfunction }\end{array}$} & 0 & 1 & 3.0 & yes & 1 \\
\hline & & & & 0 & 1 & 6.5 & yes & 1 \\
\hline & & & & 0 & 1 & 18.5 & yes & 1 \\
\hline
\end{tabular}

Table 3

General results of testing URB/ZS-3 collected during tests at Polkowice-Sieroszowice mine

\begin{tabular}{|c|c|}
\hline \multicolumn{2}{|c|}{ General statistics for tests of $\mathrm{URB} / \mathrm{ZS}-3$} \\
\hline Operating time of URB [min] & 228 \\
\hline Material delivered with bucket loader [Mg] & 385 \\
\hline Material delivered with haul truck [Mg] & 100 \\
\hline Material delivered in total $[\mathrm{Mg}]$ & 485 \\
\hline Handled material to URB operating time $[\mathrm{Mg} / \mathrm{min}]$ & 2 \\
\hline Number of shifts worked [change] & 8 \\
\hline Average of material handled per shift $[\mathrm{Mg} / \mathrm{shift}]$ & 61 \\
\hline Shift duration time [min] & 240 \\
\hline Average of material handled per minute $[\mathrm{Mg} / \mathrm{min}]$ & 1 \\
\hline Average test duration time [min] & 4.2 \\
\hline Total number of tests carried out & 55 \\
\hline Number of positive tests carried out & 21 \\
\hline Degree of positive tests $[\%]$ & 38 \\
\hline Average positive test duration time [min] & 4.8 \\
\hline
\end{tabular}


Table 3 cont.

\begin{tabular}{|c|c|}
\hline \multicolumn{2}{|c|}{ General statistics for tests of URB/ZS-3 } \\
\hline \multicolumn{2}{|c|}{ Statistics for bucket loader LKP-0903 } \\
\hline Number of tests carried out with bucket loader & 50 \\
\hline Number of positive tests carried out with bucket loader & 17 \\
\hline Degree of positive tests with bucket loader [\%] & 34 \\
\hline URB operating time with bucket loader haulage [min] & 178 \\
\hline Material delivered with bucket loader to URB operating time $[\mathrm{Mg} / \mathrm{min}]$ & 2 \\
\hline Average test duration time with bucket loader haulage [min] & 3.6 \\
\hline Average positive test duration time with bucket loader haulage [min] & 3.4 \\
\hline \multicolumn{2}{|c|}{ Statistics for WO CB4 haul truck } \\
\hline Number of tests carried out with haul truck & 5 \\
\hline Number of positive tests carried out with haul truck & 4 \\
\hline Degree of positive tests with haul truck [\%] & 80 \\
\hline URB operating time with haul truck haulage [min] & 51 \\
\hline Material delivered with truck to URB operating time [Mg/min] & 2 \\
\hline Average test duration time with haul truck haulage [min] & 10.1 \\
\hline Average positive test duration time with haul truck haulage [min] & 10.7 \\
\hline
\end{tabular}

In the initial phase of the tests (in December and January), very fine excavated material was delivered to the grate, which resulted in the optimization process focusing to a large extent on the raking of material, which did not prove to be the main mode of operation at the time of the appearance of the oversized material in February and March. It was necessary to extend the share of the lump breaking mode and to introduce an additional "single" mode. As a result of the longer cleaning times, simplifications were applied in the operation of the particular modes. Following further optimization, a satisfactory compromise was reached on March 9, 2018.

Table 4 presents the results of the tests of March 9, 2018. Eleven tests were carried out, nine of which ended with the cleaning of the grate. The average cleaning time was 4.5 minutes.

The analysis of the data from the table shows that the progress of the optimization work is at a promising level. Significant progress has been observed in the area of grate cleanliness efficiency. The testing was to be continued on March 15, 2018, in a continuous manner; however, due to the failure, it was necessary to stop the work and start the diagnostics of the defect.
The most common problems noted during the automatic operation of the URB/ZS-3 were related to the operation of the laser scanner.

Problems with the location of the excavated material due to the lack of real-time scanning on the grate were noted. This meant that the machine was not able to correct the path when implementing the set algorithm after scanning the grate until the grate was scanned again. This created problems due to the movement of excavated material on the grate during its cleaning, which resulted in the hammer operating on empty meshes of the grate or the omission of lumps. This problem remained unresolved during the optimization tests and contributed to the deterioration of the results obtained during the tests.

Fixing the scanner at an angle had a negative effect on the cleaning results and times. Oversized lumps or piles of excavated material covered the next row of meshes of the grate. The scanner interpreted such cover as excavated material in a subsequent row, which caused movements to empty meshes of the grate and an increases in the time taken to clean the grate. This problem remained unresolved during the optimization tests and contributed to the deterioration of the results obtained during the tests. 
Table 4

Results collected during testing of algorithm of URB/ZS-3 on March 9. 2018

\begin{tabular}{|l|c|}
\hline \multicolumn{2}{|c|}{ Statistics of testing performed on March 9, 2018 } \\
\hline Operating time of URB [min] & 58 \\
\hline Material delivered with bucket loader [Mg] & 105 \\
\hline Material delivered with haul truck [Mg] & 105 \\
\hline Material delivered in total [Mg] & 2 \\
\hline Handled material to URB operating time [Mg/min] & 1 \\
\hline Number of shifts worked [change] & 105 \\
\hline Average of material handled per shift [Mg/shift] & 240 \\
\hline Shift duration time [min] & 0.4 \\
\hline Average of material handled per minute [Mg/min] & 5.3 \\
\hline Average test duration time [min] & 11 \\
\hline Total number of tests carried out & 9 \\
\hline Number of positive tests carried out & 82 \\
\hline Degree of positive tests [\%] & 4.5 \\
\hline Average positive test duration time [min] & \\
\hline
\end{tabular}

The scanner was not able to distinguish the grain of the excavated material on the grate. This pointed to problems in selecting the algorithm path and carrying out the cleaning process correctly; i.e., raking oversized lumps and breaking down fine excavated material. A partial solution to the problem was the introduction of the "single" mode to the algorithm, during which the device started to break oversized material in the middle of the mass of a lump after scanning as opposed to the earlier breaking down in the middle of the meshes of the grate. Despite providing a better cleaning of the grate, the "single" mode extends the operating time, which negatively affects the measurement results.

Significant problems observed during the tests were the idle movements and the need to return the hammer to a fixed point in order to scan the excavated material again, which prolonged the operating time. An optimization was made consisting of scanning the grate at the hammer's standstill without any unnecessary additional movement, which reduced the time it took to clean the grate. An optimization was also carried out with regard to the movement of the machine on the grate during operation. Further improvements in the performance require the continuation of tests with excavated material.
Problems with the coverage of the URB/ZS-3 arm were also noted. The machine had difficulties in breaking up the lumps in the last row of meshes - the hammer used the impactor at an angle to a lump, which resulted in longer operating time and the frequent suspension of the cleaning algorithm. It was decided to reduce the scanner's field of vision by masking the last row of meshes in the grate. This resulted in a significant improvement in the operating times.

During the tests, the material supplied was occasionally contaminated with metal elements, which posed a threat to the rubber belt of the conveyor. When cleaning the grate with the operator, the operator is responsible for checking the condition of the excavated material and intervening in dangerous cases. In the case of automatic cleaning, the appearance of such elements forces a manual emergency shutdown of the program and human intervention.

The optimization tests have also shown that the design of the boom joints and swivel is very important for the proper operation of the control system. Constant and low-motion resistances at the joints and swivel make it significantly easier to determine the correct operating parameters of the control software. Therefore, it is necessary to use a central lubrication system. During the tests, however, it was found that 
the load values exceeded safe levels at certain points of the kinematic system, and excessive bearing wear occurred, which resulted in the increased displacement resistance of individual boom members. Therefore, it was necessary to frequently correct certain parameters adopted in the control software. For this reason, it seems advisable to redesign the joints and swivel in order to increase their load capacity and durability. After using a more efficient hydraulic power supply, this would increase the speed of the hammer's movement and, thus, reduce the cleaning times of the grate.

\section{SUMMARY}

The optimization tests of a prototype of the URB/ZS-3 lump breaker were aimed at adjusting the control algorithm and testing the machine under the underground conditions of the KGHM Polska Miedź S.A. mine. The optimization was based on a specific method of tests whose main aim was to ensure the shortest possible time of cleaning the grate, to a point which enabled unloading next bucket loader.

During eight mining shifts, 55 tests with excavated material were carried out in the Polkowice-Sieroszowice mine using the LK3 LKP-0903 bucket loaders (50 tests) and the WO CB4 haul trucks (5 tests), 38\% of which were successful (the grate was cleaned). The average cleaning time was 4.8 minutes. During the shift on March 9, 2018, tests were carried out to check the algorithm for the bucket loaders. As a result of the verification measurements, 11 tests were carried out, $82 \%$ of which were successfully completed (with an average cleaning time of 4.5 minutes). During the verification measurements, the machine broke down the oversized material and raked the fine material in a satisfactory way.

The cleaning algorithm is based on putting the subprograms in the modes in the right order:

- chiseling - breaking lumps in the middle of the grate meshes,

- spreading - the raking of the excavated material on the grate,

- single - breaking lumps in the middle of the mass recognized by the scanner.

Significant time savings have been made by eliminating the unnecessary idle movements during scan- ning - the scanning of the grate takes place while the machine is at the starting point of the URB/ZS-3. Further improvements to the algorithm should include real-time scanning, whereby the lump breaker can react depending on the current distribution of excavated material on the grate.

In addition, grate scanning should provide information on the grain size of the excavated material on the grate. Fine-grained excavated material requires more raking movements, while oversized excavated material should be broken down by the hydraulic hammer. In addition to information on the nature of the excavated material, the scanning should inform the operator about undesirable metal elements on the grate.

The tests with haul trucks were carried out with the URB/ZS-3 machine malfunctioning. As a result of the failure of the piston rod position sensor in the swivel actuator, the machine was decalibrated. The malfunction was caused by the incorrect choice of fastening to protect the sensor in the socket. As the URB/ZS-3 has four actuators with displacement sensors, similar failures are likely to occur in the future.

The tests showed that it is advisable to redesign the joints and swivel of the URB boom in order to increase their load capacity and durability.

\section{References}

[1] Krauze K., Rączka W., Sibielak M., Konieczny J., Kubiak D., Culer H., Bajus D.: Automated transfer point URB/ZS-3, "Mining - Informatics, Automation and Electrical Engineering" 2017, 2: 80-85.

[2] Młynarczyk J., Sawicki M., Stefaniak P., Ziętkowski L.: Wykonanie badań $i$ analizy porównawczej dwóch systemów sterowania i obstugi krat wysypowych O/ZG Polkowice-Sieroszowice tj. obecnego z udziatem operatora oraz zdalnego (sterowanie 2 punktami) wraz z ocena wplywu zmiany sposobu sterowania na pracę całego układu przeładowczego ETAP I-III, KGHM Cuprum sp. z o.o., Wrocław 2011 [unpublished].

LESZEK ZIĘTKOWSKI, Ph.D., Eng.
JANUSZ MŁYNARCZYK, Ph.D., Eng,
OJCIECH SOBOLEWSKI, M.Sc., Eng.
KGHM CUPRUM

Research \& Development Center ul. gen. Władystawa Sikorskiego 2-8, 53-659 Wroctaw, Poland

\{lzietkowski, jmlynarczyk,wsobolewski\} @cuprum.wroc.pl 


\title{
Testy optymalizacyjne pracy automatycznego urządzenia do rozbijania brył nadgabarytowych URB/ZS-3 w kopalni Polkowice-Sieroszowice
}

\begin{abstract}
$W$ artykule przedstawiono doświadczenia z pierwszego etapu testów optymalizacyjnych pracy automatycznego urzadzenia do rozbijania bryt nadgabarytowych. Testy przeprowadzono w okresie od grudnia 2017 r. do marca 2018 r. w Zaktadach Górniczych Polkowice-Sieroszowice - oddziat KGHM Polska Miedź. Automatyczne urzadzenie URB/ZS-3 powstato w ramach drugiego konkursu wspólnego przedsięwzięcia finansowanego przez NCBR i KGHM Polska Miedź S.A. pod nazwa CuBR. Omówiono przyjęte metody prowadzenia prób ruchowych urządzenia URB/ZS-3, które musiaty uwzględniać specyficzne wymagania $i$ warunki pracy oddziału górniczego w kopalni Polkowice-Sieroszowice. Punktem odniesienia dla oceny skuteczności nowego rozwiazania były czasy oczyszczania kraty przez urzadzenie pracujace $w$ trybie zdalnym. Zaprezentowano wyniki oczyszczania kraty $z$ urobku przez urządzenie pracujące $w$ trybie automatycznym dla różnych algorytmów $i$ scenariuszy uwzględnionych $w$ oprogramowaniu sterującym. Wzięto pod uwage wptyw stopnia rozdrobnienia rudy, w tym liczby bryt nadgabarytowych, na czas oczyszczania kraty. Poddano wstepnej ocenie wpływ zmian wprowadzanych $w$ tym oprogramowaniu na uzyskiwane czasy opróżniania kraty. W artykule przedstawiono również wptyw zatadunku kraty $z$ wykorzystaniem tadowarek oraz wozów odstawczych na efektywność pracy automatycznego urządzenia do rozbijania bryt nadgabarytowych. Oceniono także elementy wykonawcze urządzenia pod katem ich niezawodności oraz zaproponowano kierunki ewentualnych zmian konstrukcyjnych. W podsumowaniu zaproponowano kierunki dalszych działań zmierzajacych do optymalizacji urządzenia oraz podniesienia jego efektywności i niezawodności.
\end{abstract}

Słowa kluczowe: optymalizacja, górnictwo, rozbijanie bryt nadgabarytowych

\section{WSTĘP}

Testy automatycznego urządzenia do rozbijania brył URB/ZS-3 przeprowadzone w kopalni Polkowice-Sieroszowice odbywały się jako część pracy badawczo-rozwojowej powstającej $\mathrm{w}$ ramach przedsięwzięcia CuBR II pt. „Automatyczne urządzenie do rozbijania brył typu URB/ZS-3 w wyrobiskach podziemnych kopalni rud miedzi" dofinansowanego przez Narodowe Centrum Badań i Rozwoju oraz KGHM Polska Miedź S.A. Projekt realizowany jest w konsorcjum, którego członkami są KGHM ZANAM S.A., KGHM
CUPRUM Sp. z o.o. CB-R oraz Akademia Górniczo-Hutnicza im. Stanisława Staszica.

Przed rozpoczęciem prób dołowych opracowano metodykę przeprowadzanych testów polegającą na określeniu koniecznych do przeanalizowania kryteriów w celu oceny poprawnej pracy urządzenia do rozbijania brył oraz działania układu automatycznego sterowania.

Prototyp urządzenia został zabudowany na punkcie przesypowym w kopalni Polkowice-Sieroszowice w chodniku T-210/przecinka P-13, z kratą przesypową R-120/1 na przenośnik Legmet L-120. Następnie 
punkt przesypowy był poddawany testom optymalizacyjnym z urobkiem w okresie od grudnia 2017 r. do marca $2018 \mathrm{r}$.

W trakcie pomiarów rejestrowano czasy, w jakich urządzenie oczyszczało kratę z nadgabarytów oraz oceniano skuteczność jego działania. Ocenie poddano również mechaniczne rozwiązania automatycznego urządzenia do rozbijania brył oraz oprogramowania sterującego.

\section{AUTOMATYCZNE URZĄDZENIE DO ROZBIJANIA BRY U URB/ZS-3}

Prototyp urządzenia do rozbijania brył URB/ZS-3 powstał $\mathrm{w}$ odpowiedzi na nasilające się potrzeby KGHM Polska Miedź S.A. związane z koniecznością zwiększania poziomu automatyzacji podczas eksploatacji rudy miedzi [1]. Potrzeby te wynikają z pogarszających się warunków wydobycia - zwiększona temperatura i wilgotność powietrza oraz zagrożenie tąpaniami [2].

Dodatkowo zautomatyzowanie procesu rozbijania brył umożliwiłoby zoptymalizowanie wykorzystania czasu pracy operatorów URB, a tym samym pozwoliłoby na obniżenie kosztów wydobycia rudy miedzi. Aby zrealizować te cele, urządzenie powinno zapewnić oczyszczenie kraty bez ingerencji operatora, który pełniłby funkcję kontrolną oraz włączał się w proces oczyszczania w sposób zdalny w szczególnych przypadkach [2].

Do przeprowadzenia próby zautomatyzowania procesu rozbijania brył wykorzystano istniejące urządzenia do rozbijania brył - URB, produkcji KGHM ZANAM, co było podyktowane potrzebą optymalnej pod względem kosztów konwersji z aktualnie obowiązującego systemu rozbijania brył nadgabarytowych (rozbijanie ręczne $\mathrm{z}$ operatorem bezpośrednio na kracie oraz rozbijanie zdalne) na system pracujący w cyklu automatycznym [1].

Działanie URB/ZS-3 opiera się na skanowaniu kraty laserowym skanerem, który określając stopień zajętości kraty przez urobek, decyduje o rozpoczęciu procesu oczyszczania kraty. Koordynacja pomiędzy młotem montowanym na wysięgniku, skanerem i programem sterującym odbywa się dzięki zamontowanym czujnikom i przetwornikom kąta położenia oraz drogi [1].

\section{LOKALIZACJA}

Prototyp automatycznego urządzenia do rozbijania brył URB/ZS-3 został zabudowany na punkcie przesypowym w kopalni Polkowice-Sieroszowice w chodniku T-210/przecinka P 13 z kratą przesypową R-120/1 na przenośnik Legmet L-120. Widok zabudowanego urządzenia został przedstawiony na rysunku 1 . Schemat punktu przesypowego pokazano na rysunku 2 .

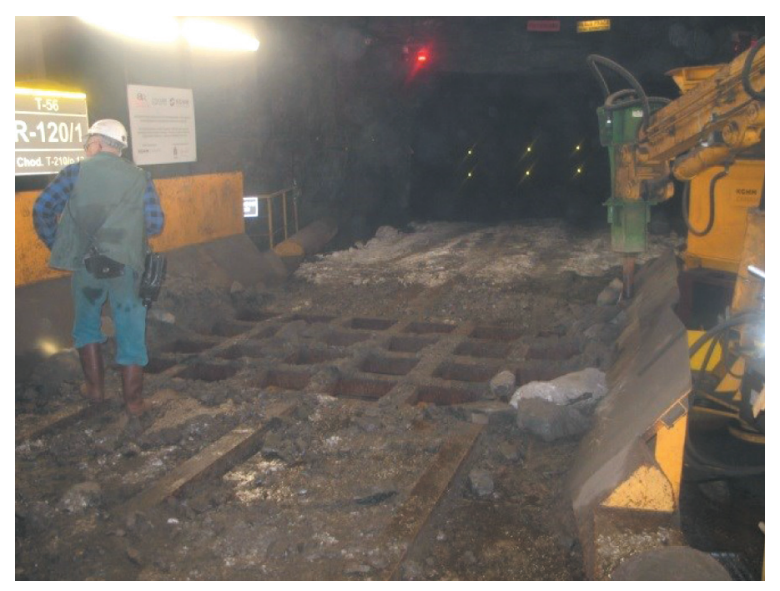

Rys. 1. Widok zabudowanego URB/ZS-3 $w$ kopalni Polkowice-Sieroszowice

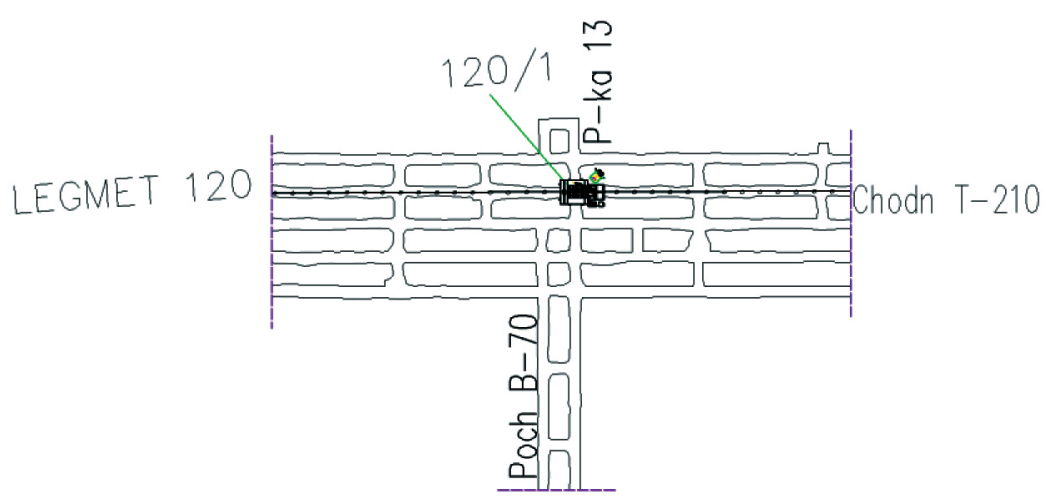

Rys. 2. Lokalizacja URB/ZS-3 w kopalni Polkowice-Sieroszowice 
Jednocześnie w sterowni SK-2 na podszybiu szybu SW-1 zostało zabudowane stanowisko obsługowe URB/ZS-3 wyposażone w konsolę zdalnego sterowania oraz szafy sterownicze umożliwiające wykonywanie pracy zdalnej na kracie. Sposób zabudowy konsoli w sterowni został przedstawiony na rysunku 3.

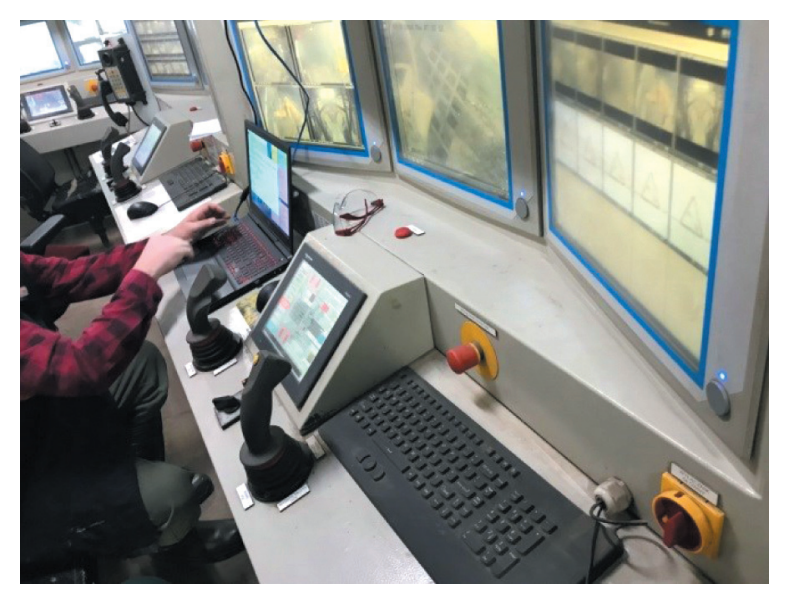

Rys. 3. Konsola zdalnego sterowania w sterowni SK-2 na podszybiu szybu SW-1

Sterownia posiada dostęp do monitoringu kraty R120/1 oraz pozwala na kontrolę nad sygnalizacją wjazdową, dzięki czemu możliwa jest współpraca z operatorem maszyny odstawczej.

\section{KRYTERIA OCENY}

Testy poprzedzono przygotowaniem odpowiednich zasad oceny poprawności działania automatycznego urządzenia do rozbijania brył URB/ZS-3. Ocenie zostały poddane poprawność pracy samego urządzenia oraz sposób działania algorytmu sterującego [2].

Za podstawowe parametry określenia zdolności do pracy urządzenia do rozbijania brył przyjęto:

- poprawność działania układu hydraulicznego wysięgnika z młotem udarowym,

- brak przecieków w układzie hydraulicznym,

- poprawność nastaw zaworu bezpieczeństwa,

- poprawność działania układu automatycznego smarowania,

- poprawność działania skanera laserowego,

- poprawność działania układu podawacza szufladowego,

- możliwe przejęcie kontroli zdalnej urządzenia ze sterowni SK-2 na podszybiu szybu SW-1.
Jako podstawowe parametry do sprawdzenia podczas pracy algorytmu sterującego przyjęto [1]:

- czas trwania cyklu samooczyszczania kraty przesypowej,

- stopień oczyszczenia kraty po zakończeniu cyklu pracy urządzenia,

- wpływ rodzaju urobku (stopień rozdrobnienia, zawilgocenie itp.) na czas trwania cyklu samooczyszczania kraty przesypowej,

- wpływ rodzaju urobku na stopień oczyszczenia kraty po zakończeniu cyklu urządzenia,

- poprawność oceny rozłożenia urobku na kracie przesypowej przez skaner laserowy,

- zdolność urządzenia do wyszukiwania urobku i pomijania pustych obszarów kraty przesypowej,

- zdolność urządzenia do wyszukiwania i rozbijania brył nadgabarytowych,

- zdolność urządzenia do wyszukiwania i przegarniania drobnego urobku,

- poprawność działania bramek wjazdowych automatycznie załączających urządzenie.

\section{TESTY OPTYMALIZACYJNE}

Przeprowadzono pięć optymalizujących prób dołowych ulepszających działanie algorytmu pod kątem sprawności i szybkości oczyszczania kraty. Do testów wykorzystano ładowarki łyżkowe LKP-0903 produkcji KGHM ZANAM o ładowności około $7 \mathrm{Mg}$ urobku. Zaplanowane prace optymalizujące $\mathrm{z}$ wozami odstawczymi WO CB4 o ładowności $20 \mathrm{Mg}$ urobku odbyły się $\mathrm{w}$ niepełnym wymiarze $\mathrm{z}$ uwagi na awarię urządzenia w marcu $2018 \mathrm{r}$.

Urobek użyty podczas prób obejmował pełen zakres ziarnistości spotykanej w kopalniach KGHM Polska Miedź S.A. Miało to na celu umożliwienie dostosowania algorytmu do zmieniających się warunków na kracie przesypowej, zależnych od rodzaju urobku, lokalizacji oddziału wydobywczego oraz ogólnej zmienności uziarnienia urobku wynikającej z zastosowania metody urabiania przodków za pomocą materiałów wybuchowych w filarowo-komorowym systemie eksploatacji.

Próby miały na celu opracowanie odpowiednich parametrów i nastaw w algorytmach sterujących polepszających czas pracy URB/ZS-3 oraz zapewniających odpowiedni dla użytkownika stosunek czasu trwania cyklu oczyszczania do stopnia oczyszczenia kraty z urobku [1]. 
Testy optymalizacyjne polegały na określeniu koniecznych do wprowadzenia modyfikacji w oprogramowaniu oraz wyznaczeniu akceptowalnego do zachowania ciągłości odstawy stopnia zajętości kraty, który umożliwia w razie takiej potrzeby przejazd maszyn odstawczych przez kratę [1].

Przykład kraty przed oczyszczeniem zaprezentowano na rysunku 4. Na kratę dostarczono około $7 \mathrm{Mg}$ urobku o charakterystyce drobnej. Na rysunku 5 zaprezentowano kratę po oczyszczeniu automatycznym urządzeniem do rozbijania brył URB/ZS-3. Stopień oczyszczenia kraty uznano za zadowalający.

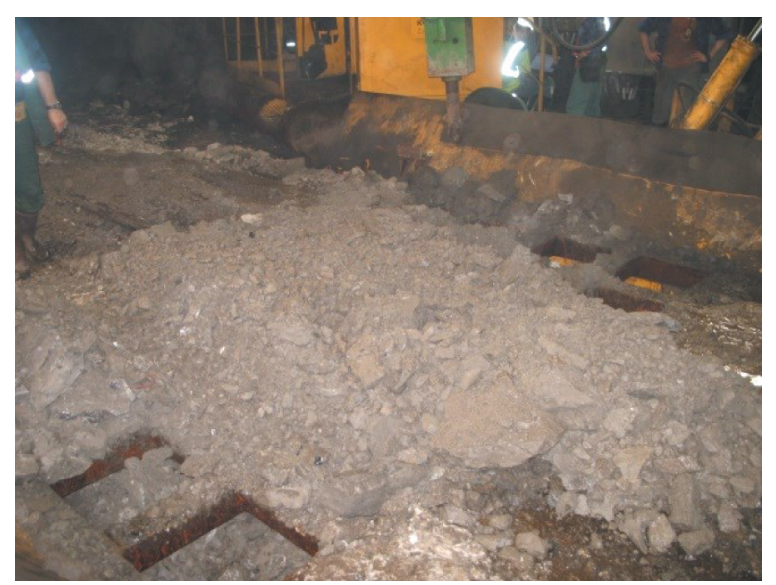

Rys. 4. Krata po wytadowaniu urobku przez ładowarkę tyżkowa LKP-0903

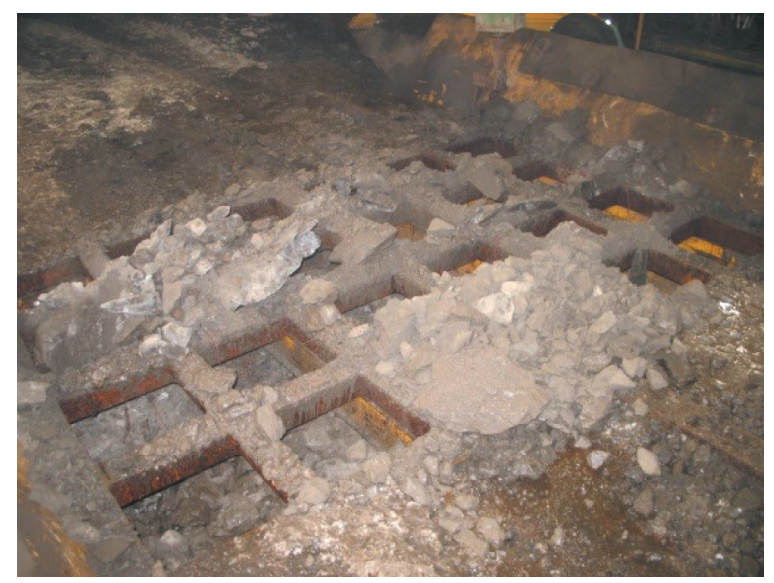

Rys. 5. Krata po oczyszczeniu automatycznym przez $U R B / Z S-3$

W wyniku prób optymalizacyjnych wprowadzono w algorytmie oczyszczającym trzy tryby pracy:

- rozbijanie brył w oczkach kraty (tryb dłutowania),

- przegarnianie urobku po kracie (tryb rozgarniania),

- rozbijanie brył w ich środku geometrycznym określanym na podstawie skanowania (tryb „single”).
Po procesie optymalizacji tryby oczyszczające zostały znacząco uproszczone w celu skrócenia czasu programu czyszczącego. W początkowej fazie testów tryb dłutowania polegał na wstępnym przegarnięciu urobku z przęseł oczka kraty, a następnie na rozbiciu bryły w środku oczka kraty. W ramach prowadzonych testów program został uproszczony i w aktualnej wersji polega na wykonaniu najazdu młota nad środek geometryczny oczka kraty. Następnie urządzenie opuszcza się i w momencie napotkania oporu bryły uruchamia udar w młocie hydraulicznym.

Tryb rozgarniania został uproszczony z początkowego przejazdu wzdłuż przęseł kraty do przejazdów skośnych. Takie rozwiązanie znacznie przyspiesza oczyszczenie kraty $\mathrm{z}$ drobnego urobku w porównaniu z poprzednim rozwiązaniem. Tryb „single” został wprowadzony pod koniec trwania testów. Służy do rozbijania brył w ostatniej fazie pracy algorytmu po wykonaniu trybów przegarniających i rozgarniających.

Tryby zostały uporządkowane w scenariusze uruchamiane w zależności od typu maszyny dostarczającej urobek - wóz odstawczy/ładowarka łyżkowa oraz w zależności od stopnia zajętości kraty.

Stopień zajętości kraty był określany na podstawie skanowania wykonywanego przed realizacją i w trakcie realizacji scenariusza oczyszczającego. Urządzenie powinno kontynuować proces oczyszczania do momentu osiągnięcia ustalonej wartości, po czym umożliwić wjazd kolejnej maszyny z urobkiem. W wyniku testów optymalizacyjnych wyznaczono zadowalającą wartość graniczną na poziomie $17 \%$ zajętości kraty. Wartość wysokości urobku umożliwiającą swobodny przejazd maszyny określono w wyniku testów optymalizacyjnych na poziomie $150 \mathrm{~mm}$ nad kratą.

Układ sterujący po wyładowaniu urobku na kratę odczytuje stopień zajętości i załącza URB/ZS-3, w momencie gdy dostarczony urobek wypełnia kratę powyżej 17\% stopnia zajętości. Praca oczyszczająca jest kontynuowana do momentu uzyskania zajętości poniżej $17 \%$.

W trakcie pomiarów rejestrowano czasy trwania poszczególnych cykli od momentu załączenia automatycznego trybu samooczyszczania do powrotu młota hydraulicznego URB do punktu bazowego oraz określano skuteczność i stopień oczyszczenia kraty po każdym pomiarze. Dodatkowo w celu jak najlepszego odwzorowania warunków eksploatacyjnych na $15 \mathrm{~s}$ przed uruchomieniem URB/ZS-3 załączał się podawacz szufladowy kraty R-120/1, który umożliwiał wstępne przesypanie się drobnego urobku - samooczyszczanie się kraty. 
Podczas normalnej eksploatacji planowane jest zapewnienie sterowania ruchem maszyn odstawczych w obrębie kraty przez system URB/ZS-3. To sterowanie sygnalizacją świetlną, która czerpie informacje między innymi ze specjalnych bramek zabudowanych na wjazdach na kratę. Podczas prób optymalizacyjnych nie testowano sygnalizacji wjazdu na kratę przez operatora. Zielone światło i zgodę na wjazd na kratę wydawał operator nadzorujący ze sterowni SK-2 [2].

Czasy poszczególnych pomiarów oraz wyniki testów zaprezentowano w tabeli 1 dla prób optymalizacyjnych oraz tabeli 2 dla testów sprawdzających algorytm. Krata zostawała uznana za oczyszczoną, jeżeli po zakończeniu próby stan zajętości kraty umożliwiał ponowny załadunek urobku.

Testy optymalizacyjne URB/ZS-3 zostały przeprowadzone na pięciu zmianach górniczych, w trakcie których wykonano 39 pomiarów z użyciem około 280 Mg urobku (40 łyżek ładowarki LKP-0903), z których osiem zakończyło się oczyszczeniem kraty. Średni czas trwania próby pozytywnej od momentu uruchomienia URB/ZS-3 do wyłączenia wynosił $126 \mathrm{~s}$.

Testy sprawdzające URB/ZS-3 zostały przeprowadzone na trzech zmianach roboczych, jednak w wyniku awarii urządzenia podczas pierwszych prób z wozami odstawczymi, w drugim dniu testów konieczne było przerwanie prób.

Na zmianie pierwszej dokonano jedenastu pomiarów z użyciem około $105 \mathrm{Mg}$ urobku (piętnaście łyżek ładowarki LKP-0903), z których dziewięć zakończyło się oczyszczeniem kraty. Średni czas trwania próby pozytywnej od momentu uruchomienia URB/ZS-3 do wyłączenia wynosił $293 \mathrm{~s}$.

W trakcie prób 15.03.2018 r. doszło do awarii urządzenia. Uszkodzeniu uległo mocowanie czujnika położenia tłoczyska siłownika obrotu URB/ZS-3, co spowodowało rozkalibrowanie się urządzenia i zgubienie punktu zero młota hydraulicznego. $\mathrm{Z}$ uwagi na konstrukcję układu pomiarowego (czujnik mocowany w tłoczysku) konieczna była wymiana całego siłownika obrotu. Po analizie stwierdzono, że awaria mocowania czujnika położenia tłoczyska w siłowniku obrotu nastąiła w wyniku nieprawidłowego zabezpieczenia czujnika w gnieździe mocującym. Zastosowano żywicę poliuretanową, która pod wpływem temperatury czynnika roboczego uległa zniszczeniu. Niezabezpieczony czujnik podczas pracy udarowej URB/ZS-3 zaczął się przesuwać, co spowodowało rozkalibrowanie maszyny.
$\mathrm{Z}$ uwagi na fakt, że czujniki położenia drogi montowane są we wszystkich czterech siłownikach urządzenia do rozbijania brył, należy rozważyć zmianę przyjętej koncepcji zabezpieczenia czujnika i rejestrowania wysuwu tłoczyska.

Awaria uniemożliwiła przeprowadzenie pełnych testów odstawy za pomocą wozów odstawczych CB4 oraz odpowiedniej optymalizacji algorytmu. Testy optymalizacyjne $\mathrm{z}$ wozem odstawczym były prowadzone równolegle do napraw rozkalibrowanego URB/ZS-3.

W tabeli 3 zaprezentowano statystyki ogólne dla prób przeprowadzonych na punkcie przesypowym z wykorzystaniem automatycznego urządzenia do rozbijania brył URB/ZS-3. Testy optymalizacyjne były prowadzone na ośmiu zmianach górniczych w terminie od grudnia 2017 r. do marca 2018 r. Przeprowadzono łącznie 55 prób, z czego 21 zakończyło się oczyszczeniem kraty, co daje 38\% skuteczności. Średni czas oczyszczenia wynosił 4,8 min. 50 prób zostało przeprowadzonych z użyciem ładowarek łyżkowych, z czego 17 zakończyło się oczyszczeniem kraty. Średni czas oczyszczenia wynosił $3,4 \mathrm{~min}$. W tabeli ujęto również statystyki dla prób z wykorzystaniem wozu odstawczego. Wykonano pięć prób, z czego cztery zakończyły się oczyszczeniem kraty. Średni czas oczyszczenia wynosił $10,7 \mathrm{~min}$.

Należy zaznaczyć, że próby prowadzone w okresie optymalizacyjnym miały charakter badawczo-sprawdzający. Dochodziło do przerw w trakcie trwania pomiarów i zmian w parametrach algorytmu. Stąd występujący niski stopień powodzenia przeprowadzonych prób oraz niskie zmianowe wykorzystanie URB/ZS-3. Optymalizację oprogramowania dodatkowo utrudniał zmieniający się charakter urobku urobek drobniejszy wymaga większego udziału trybu przegarniającego $\mathrm{w}$ porównaniu $\mathrm{z}$ urobkiem $\mathrm{z}$ większym udziałem nadgabarytów.

W początkowej fazie testów - grudzień i styczeń, dostarczano na kratę bardzo drobny urobek, co spowodowało, że w procesie optymalizacji skupiono się w dużym stopniu na przegarnianiu urobku, które w momencie pojawienia się nadgabarytów w lutym i marcu nie sprawdziło się jako główny tryb pracy. Konieczne było rozszerzenie udziału trybu rozbijania brył oraz wprowadzenie dodatkowego trybu ,single”. W wyniku wydłużających się czasów oczyszczania zastosowano uproszczenia w działaniu poszczególnych trybów. W wyniku dalszej optymalizacji osiągnięto zadowalający kompromis w dniu 09.03.2018 r. 
Tabela 1

Wyniki pomiarów prób optymalizujących automatycznego urządzenia do rozbijania brył URB/ZS-3

\begin{tabular}{|c|c|c|c|c|c|c|c|c|}
\hline \multirow{2}{*}{ Data prób } & \multirow{2}{*}{$\begin{array}{c}\text { Liczba } \\
\text { prób }\end{array}$} & \multirow{2}{*}{$\begin{array}{l}\text { Liczba prób } \\
\text { pozytywnych }\end{array}$} & \multirow{2}{*}{$\begin{array}{l}\text { Dodatkowe } \\
\text { informacje }\end{array}$} & \multicolumn{2}{|c|}{ Urobek } & \multirow{2}{*}{$\begin{array}{c}\text { Czas trwania } \\
\text { pracy URB } \\
{[\text { min] }}\end{array}$} & \multirow{2}{*}{\multicolumn{2}{|c|}{$\begin{array}{c}\text { Próba } \\
\text { pozytywna }\end{array}$}} \\
\hline & & & & $\begin{array}{c}\text { ladowarka } \\
\text { [lyżka] }\end{array}$ & wóz & & & \\
\hline \multirow{4}{*}{ 19.12.2017 } & \multirow{4}{*}{4} & \multirow{4}{*}{1} & \multirow{4}{*}{$\begin{array}{c}\text { próby } \\
\text { optymalizacyjne }\end{array}$} & 3 & 0 & 5,0 & nie & 0 \\
\hline & & & & 1 & 0 & 8,0 & nie & 0 \\
\hline & & & & 1 & 0 & 4,0 & tak & 1 \\
\hline & & & & 3 & 0 & 8,0 & nie & 0 \\
\hline \multirow{2}{*}{12.01 .2018} & \multirow{2}{*}{2} & \multirow{2}{*}{0} & \multirow{2}{*}{$\begin{array}{c}\text { próby } \\
\text { optymalizacyjne }\end{array}$} & 5 & 0 & brak próby & nie & 0 \\
\hline & & & & 4 & 0 & brak próby & nie & 0 \\
\hline \multirow{8}{*}{31.01 .2018} & \multirow{8}{*}{8} & \multirow{8}{*}{6} & \multirow{8}{*}{$\begin{array}{c}\text { próby } \\
\text { optymalizacyjne }\end{array}$} & 2 & 0 & 1,5 & tak & 1 \\
\hline & & & & 1 & 0 & 1,7 & tak & 1 \\
\hline & & & & 1 & 0 & 1,5 & tak & 1 \\
\hline & & & & 1 & 0 & 1,8 & tak & 1 \\
\hline & & & & 1 & 0 & 1,7 & tak & 1 \\
\hline & & & & 1 & 0 & 3,5 & nie & 0 \\
\hline & & & & 3 & 0 & 3,0 & tak & 1 \\
\hline & & & & 3 & 0 & 2,8 & nie & 0 \\
\hline \multirow{17}{*}{02.02 .2018} & \multirow{17}{*}{17} & \multirow{17}{*}{1} & \multirow{17}{*}{$\begin{array}{c}\text { próby } \\
\text { optymalizacyjne }\end{array}$} & 1 & 0 & 1,7 & nie & 0 \\
\hline & & & & pop. próba & 0 & 1,7 & tak & 1 \\
\hline & & & & 1 & 0 & 1,7 & nie & 0 \\
\hline & & & & pop. próba & 0 & 2,8 & nie & 0 \\
\hline & & & & 1 & 0 & 1,5 & nie & 0 \\
\hline & & & & 1 & 0 & 3,3 & nie & 0 \\
\hline & & & & pop. próba & 0 & 3,8 & nie & 0 \\
\hline & & & & pop. próba & 0 & 3,7 & nie & 0 \\
\hline & & & & 1 & 0 & 3,0 & nie & 0 \\
\hline & & & & pop. próba & 0 & 5,5 & nie & 0 \\
\hline & & & & pop. próba & 0 & 2,0 & nie & 0 \\
\hline & & & & pop. próba & 0 & 1,0 & nie & 0 \\
\hline & & & & pop. próba & 0 & 6,3 & nie & 0 \\
\hline & & & & pop. próba & 0 & 2,5 & nie & 0 \\
\hline & & & & pop. próba & 0 & 1,3 & nie & 0 \\
\hline & & & & pop. próba & 0 & 0,8 & nie & 0 \\
\hline & & & & 1 & 0 & 2,0 & nie & 0 \\
\hline \multirow{8}{*}{28.02 .2018} & & & & 1 & 0 & 1,0 & nie & 0 \\
\hline & & & & pop. próba & 0 & 7,0 & nie & 0 \\
\hline & & & & pop. próba & 0 & 6,0 & nie & 0 \\
\hline & 8 & 0 & próby & 1 & 0 & 3,0 & nie & 0 \\
\hline & & & optymalizacyjne & 1 & 0 & 3,9 & nie & 0 \\
\hline & & & & pop. próba & 0 & 3,1 & nie & 0 \\
\hline & & & & 1 & 0 & 7,0 & nie & 0 \\
\hline & & & & pop. próba & 0 & 1,5 & nie & 0 \\
\hline
\end{tabular}


Tabela 2

Wyniki prób sprawdzających automatycznego urządzenia do rozbijania brył URB/ZS-3

\begin{tabular}{|c|c|c|c|c|c|c|c|c|}
\hline \multirow{2}{*}{ Data prób } & \multirow{2}{*}{$\begin{array}{l}\text { Liczba } \\
\text { prób }\end{array}$} & \multirow{2}{*}{$\begin{array}{l}\text { Liczba prób } \\
\text { pozytywnych }\end{array}$} & \multirow{2}{*}{$\begin{array}{l}\text { Dodatkowe } \\
\text { informacje }\end{array}$} & \multicolumn{2}{|c|}{ Urobek } & \multirow{2}{*}{$\begin{array}{c}\text { Czas } \\
\text { trwania } \\
\text { pracy URB } \\
{[\text { min] }}\end{array}$} & \multirow{2}{*}{\multicolumn{2}{|c|}{$\begin{array}{c}\text { Próba } \\
\text { pozytywna }\end{array}$}} \\
\hline & & & & ladowarka & wóz & & & \\
\hline \multirow{11}{*}{ 09.03.2018 } & \multirow{11}{*}{11} & \multirow{11}{*}{9} & \multirow{11}{*}{$\begin{array}{c}\text { próby } \\
\text { testujące algorytm }\end{array}$} & 3 & 0 & 6,0 & tak & 1 \\
\hline & & & & 1 & 0 & 4,0 & tak & 1 \\
\hline & & & & 1 & 0 & 11,0 & nie & 0 \\
\hline & & & & 1 & 0 & 6,5 & nie & 0 \\
\hline & & & & 1 & 0 & 10,7 & tak & 1 \\
\hline & & & & 2 & 0 & 4,0 & tak & 1 \\
\hline & & & & 2 & 0 & 3,0 & tak & 1 \\
\hline & & & & 1 & 0 & 4,0 & tak & 1 \\
\hline & & & & 1 & 0 & 4,3 & tak & 1 \\
\hline & & & & 1 & 0 & 3,3 & tak & 1 \\
\hline & & & & 1 & 0 & 1,5 & tak & 1 \\
\hline \multirow{2}{*}{15.03 .2018} & \multirow{2}{*}{2} & \multirow{2}{*}{1} & \multirow{2}{*}{$\begin{array}{l}\text { nieprawidłowe } \\
\text { działanie }\end{array}$} & 0 & 1 & 14,7 & tak & 1 \\
\hline & & & & 0 & 1 & 8,0 & nie & 0 \\
\hline \multirow{3}{*}{ 16.03.2018 } & \multirow{3}{*}{3} & \multirow{3}{*}{3} & \multirow{3}{*}{$\begin{array}{l}\text { nieprawidłowe } \\
\text { działanie }\end{array}$} & 0 & 1 & 3,0 & tak & 1 \\
\hline & & & & 0 & 1 & 6,5 & tak & 1 \\
\hline & & & & 0 & 1 & 18,5 & tak & 1 \\
\hline
\end{tabular}

Tabela 3

Statystyki ogólne testów URB/ZS-3 zebranych podczas prób w kopalni Polkowice-Sieroszowice

\begin{tabular}{|c|c|}
\hline \multicolumn{2}{|c|}{ Statystyki ogólne testów URB/ZS-3 } \\
\hline Czas pracy URB [min] & 228 \\
\hline Urobek dostarczony ładowarką łyżkową [Mg] & 385 \\
\hline Urobek dostarczony wozem odstawczym [Mg] & 100 \\
\hline Urobek dostarczony łącznie $[\mathrm{Mg}]$ & 485 \\
\hline Przeładowany urobek do czasu pracy URB [Mg/min] & 2 \\
\hline Liczba przepracowanych zmian [zmiana] & 8 \\
\hline Średni przeładunek urobku na zmianę [Mg/zmiana] & 61 \\
\hline Czas trwania zmiany [min] & 240 \\
\hline Średni przeładunek urobku na minutę [Mg/min] & 1 \\
\hline Średni czas trwania próby [min] & 4,2 \\
\hline Liczba przeprowadzonych prób łącznie & 55 \\
\hline Liczba przeprowadzonych prób pozytywnych & 21 \\
\hline Stopień prób pozytywnych [\%] & 38 \\
\hline Średni czas trwania próby pozytywnej [min] & 4,8 \\
\hline
\end{tabular}


Tabela $3 \mathrm{~cd}$.

\begin{tabular}{|c|c|}
\hline \multicolumn{2}{|c|}{ Statystyki ogólne testów URB/ZS-3 } \\
\hline \multicolumn{2}{|c|}{ Statystyki dla ładowarki łyżkowej LKP-0903 } \\
\hline Liczba przeprowadzonych prób z ładowarką łyżkową & 50 \\
\hline Liczba przeprowadzonych prób pozytywnych z ładowarką łyżkową & 17 \\
\hline Stopień prób pozytywnychz ładowarką łyżkową [\%] & 34 \\
\hline Czas pracy URB z odstawą ładowarką łyżkową [min] & 178 \\
\hline Urobek dostarczony ładowarką łyż. do czasu pracy URB [Mg/min] & 2 \\
\hline Średni czas trwania próby z odstawą ładowarką łyżkową [min] & 3,6 \\
\hline Średni czas trwania próby pozytywnej z odstawą ładowarką łyżkową [min] & 3,4 \\
\hline \multicolumn{2}{|c|}{ Statystyki dla wozu odstawczego WO CB4 } \\
\hline Liczba przeprowadzonych prób z wozem odstawczym & 5 \\
\hline Liczba przeprowadzonych prób pozytywnych z wozem odstawczym & 4 \\
\hline Stopień prób pozytywnych z wozem odstawczym [\%] & 80 \\
\hline Czas pracy URB z odstawą wozem odstawczym & 51 \\
\hline Urobek dostarczony wozem do czasu pracy URB [Mg/min] & 2 \\
\hline Średni czas trwania próby z odstawą wozem odstawczym [min] & 10,1 \\
\hline Średni czas trwania próby pozytywnej z odstawą wozem odstawczym [min] & 10,7 \\
\hline
\end{tabular}

W tabeli 4 zaprezentowano statystyki prób testujących z dnia 09.03.2018 r. Przeprowadzono 11 prób, z czego dziewięć zakończyło się oczyszczeniem kraty. Średni czas oczyszczenia wynosił 4,5 min.

Analiza danych z tabeli pozwala na stwierdzenie, iż zaawansowanie prac optymalizacyjnych jest na obiecującym poziomie. Zaobserwowano znaczną poprawę oczyszczania kraty. Próby testujące miały być kontynuowane w dniu 15.03.2018 r. w trybie ciagłym, jednak na skutek awarii konieczne było przerwanie prac i rozpoczęcie diagnostyki usterki.

Najczęstsze problemy, jakie odnotowano podczas automatycznej pracy URB/ZS-3, związane były z pracą skanera laserowego.

Odnotowano problemy z lokalizacją urobku wynikające $\mathrm{z}$ braku skanowania kraty w czasie rzeczywistym. Oznaczało to, że urządzenie po zeskanowaniu kraty nie miało możliwości korekty ścieżki przy realizacji ustalonego algorytmu do czasu ponownego zeskanowania kraty. Tworzyło to problemy wynikające z ruchu urobku na kracie podczas jej oczyszczania, co skutkowało pracą młota na pustych oczkach kraty lub pomijaniem brył. Problem ten podczas prób optyma- lizacyjnych pozostał nierozwiązany i wpływa na pogorszenie wyników otrzymanych podczas prób.

Zamocowanie skanera pod kątem miało negatywny wpływ na wyniki oraz czasy oczyszczania. Nadgabaryty lub pryzmy urobku powodowały zasłonięcie kolejnego rzędu oczek kraty. Skaner interpretował takie zasłonięcie jako urobek w kolejnym rzędzie, co powodowało ruchy do pustych oczek kraty i wydłużenie czasu jej oczyszczenia. Problem ten podczas prób optymalizacyjnych pozostał nierozwiązany i wpływa na pogorszenie wyników otrzymanych podczas prób.

Skaner nie miał możliwości rozróżnienia ziarnistości urobku na kracie. Oznaczało to problemy z wyborem ścieżki algorytmu i z poprawnym przeprowadzeniem procesu oczyszczania - przegarnianie nadgabarytów i rozbijanie drobnego urobku. Częściowym rozwiązaniem problemu było wprowadzenie do algorytmu trybu „single”, podczas którego po wykonaniu skanu urządzenie rozpoczynało rozbijanie nadgabarytów w środku masy bryły w przeciwieństwie do wcześniejszego rozbijania w środku oczek kraty. Tryb „single” pomimo zapewnienia lepszego oczyszczenia kraty wydłuża czas pracy, co negatywnie przekłada się na wyniki pomiarów. 
Tabela 4

Statystyki zebrane podczas prób testujących algorytm URB/ZS-3 w dniu 09.03.2018 r.

\begin{tabular}{|l|c|}
\hline \multicolumn{2}{|c|}{ Statistics of testing performed on March 9, 2018 } \\
\hline Czas pracy URB [min] & 58 \\
\hline Urobek dostarczony ładowarką łyżkową [Mg] & 105 \\
\hline Urobek dostarczony wozem odstawczym [Mg] & 0 \\
\hline Urobek dostarczony łącznie [Mg] & 105 \\
\hline Przeładowany urobek do czasu pracy URB [Mg/min] & 2 \\
\hline Liczba przepracowanych zmian [zmiana] & 1 \\
\hline Średni przeładunek urobku na zmianę [Mg/zmiana] & 105 \\
\hline Czas trwania zmiany [min] & 240 \\
\hline Średni przeładunek urobku na minutę [Mg/min] & 0,4 \\
\hline Średni czas trwania próby [min] & 5,3 \\
\hline Liczba przeprowadzonych prób łącznie & 11 \\
\hline Liczba przeprowadzonych prób pozytywnych & 9 \\
\hline Stopień pozytywnych prób [\%] & 82 \\
\hline Średni czas trwania próby pozytywnej [min] & 4,5 \\
\hline
\end{tabular}

Znaczącym problemem zaobserwowanym podczas prób było wykonywanie jałowych ruchów oraz konieczność powrotu młota do ustalonego punktu w celu kolejnego zeskanowania urobku, co wydłużało czas pracy. Dokonano optymalizacji polegającej na skanowaniu kraty w miejscu postojowym młota bez konieczności zbędnych ruchów, co przełożyło się na zmniejszenie czasu oczyszczania kraty. Poprawiono aspekt poruszania się urządzenia po kracie w trakcie pracy. Dalsza poprawa parametrów wymaga kontynuowania testów z urobkiem.

Odnotowano również problemy z zasięgiem ramienia URB/ZS-3. Urządzenie miało trudności w rozbijaniu brył w ostatnim rzędzie oczek kraty - młot urządzenia używał udaru pod kątem w stosunku do bryły, co powodowało wydłużenie czasu pracy oraz częste zawieszenie algorytmu oczyszczającego. Zdecydowano się na zmniejszenie pola widzenia skanera przez zamaskowanie ostatniego rzędu oczek kraty. Spowodowało to znaczące polepszenie czasów pracy urządzenia.

W trakcie prowadzenia testów w dostarczanym urobku sporadycznie występowały elementy metalowe, stanowiące zagrożenie dla gumowej taśmy przenośnika. Podczas oczyszczania kraty z operatorem jest on odpowiedzialny za kontrolę stanu urobku oraz ingerencję w niebezpiecznych przypadkach. W sytuacji oczyszczania automatycznego pojawienie się takich elementów wymusza ręczne wyłączenie awaryjne programu i ingerencję ludzką.

Testy optymalizacyjne wykazały również bardzo duże znaczenie konstrukcji przegubów wysięgnika i obrotnicy dla prawidłowej pracy układu sterującego. Stałe i niskie opory ruchu na przegubach i na obrotnicy znacząco ułatwiają ustalenie prawidłowych parametrów pracy oprogramowania sterującego. Stąd konieczność stosowania układu centralnego smarowania. Podczas testów stwierdzono jednak, że wartości obciążeń w pewnych punktach układu kinematycznego przekraczały bezpieczny poziom i dochodziło do nadmiernego zużycia łożysk, co skutkowało wzrostem oporów przemieszczania poszczególnych członów wysięgnika. Stąd konieczne było częste korygowanie parametrów identyfikujących urobek przyjętych w oprogramowaniu sterującym. Dlatego wydaje się celowe przeprojektowanie przegubów i obrotnicy w celu zwiększenia ich nośności i trwałości. Pozwoliłoby to, po zastosowaniu wydajniejszego zasilacza hydraulicznego, na zwiększenie prędkości przemieszczania młota, a tym samym na skrócenie czasu oczyszczania kraty. 


\section{PODSUMOWANIE}

Testy optymalizacyjne prototypu urządzenia do rozbijania brył URB/ZS-3 miały na celu dostosowanie algorytmu sterującego oraz sprawdzenie urządzenia w warunkach dołowych kopalni KGHM Polska Miedź S.A. Optymalizacja prowadzona była z wykorzystaniem określonej metody prowadzonych prób, której nadrzędnym celem było zapewnić możliwie najkrótszy czas oczyszczenia kraty, do stanu umożliwiającego wysypanie kolejnej porcji urobku.

Podczas ośmiu zmian górniczych przeprowadzono 55 prób z urobkiem w warunkach kopalni Polkowice-Sieroszowice przy wykorzystaniu ładowarek łyżkowych LK3 LKP-0903 (50 prób) oraz wozów odstawczych WO CB4 (5 prób), z których 38\% zakończyło się powodzeniem i oczyszczeniem kraty. Średnie czasy oczyszczenia wynosily 4,8 min. Podczas zmiany w dniu 09.03.2018 r. przeprowadzono testy sprawdzające algorytm dla ładowarek łyżkowych. W wyniku pomiarów sprawdzających przeprowadzono 11 prób, z których $82 \%$ zakończyło się powodzeniem ze średnim czasem oczyszczania wynoszącym 4,5 min. Podczas pomiarów sprawdzających urządzenie rozbijało nadgabaryty oraz przegarniało urobek drobny w sposób zadowalający.

Algorytm czyszczący opiera się na uszeregowaniu w odpowiedniej kolejności podprogramów w trybach:

- dłutowania - rozbijania brył w środku oczek kraty,

- rozgarniania - przegarniania urobku na kracie,

- „single” - rozbijania brył w rozpoznanym przez skaner środku masy.

Ograniczono czasy trwania zbędnych ruchów jałowych podczas skanowania - skan kraty odbywa się $\mathrm{w}$ momencie przebywania urządzenia $\mathrm{w}$ punkcie startowym URB/ZS-3. Dalsze ulepszenie algorytmu powinno uwzględniać umożliwienie skanowania w czasie rzeczywistym, dzięki któremu urządzenie do rozbijania brył mogłoby reagować w zależności od bieżącego rozłożenia urobku na kracie.
Ponadto skan kraty powinien dostarczyć informację dotyczącą ziarnistości urobku na kracie. Urobek drobnoziarnisty wymaga wprowadzenia większej liczby ruchów przegarniających, natomiast urobek nadgabarytowy powinien być rozbijany uderzeniem młota hydraulicznego. Oprócz informacji dotyczącej charakteru urobku skan powinien informować operatora o niepożądanych elementach metalowych na kracie.

Próby z wozami odstawczymi były prowadzone przy niesprawnym urządzeniu URB/ZS-3. W wyniku awarii czujnika położenia tłoczyska $\mathrm{w}$ siłowniku obrotu doszło do rozkalibrowania urządzenia. Usterka została spowodowana niewłaściwym doborem mocowania zabezpieczającego czujnik w gnieździe. $\mathrm{Z}$ uwagi na to, że URB/ZS-3 ma cztery siłowniki hydrauliczne wyposażone w czujniki przemieszczenia, istnieje prawdopodobieństwo wystąienia podobnych awarii w przyszłości.

Próby wykazały również, że celowe jest przeprojektowanie przegubów i obrotnicy wysięgnika URB, w celu zwiększenia ich nośności i trwałości.

\section{Literatura}

[1] Krauze K., Raczka W., Sibielak M., Konieczny J., Kubiak D., Culer H., Bajus D.: Automated transfer point $U R B / Z S-3$, „Mining - Informatics, Automation and Electrical Engineering" 2017, 2: 80-85.

[2] Młynarczyk J., Sawicki M., Stefaniak P., Ziętkowski L.: $W y$ konanie badań $i$ analizy porównawczej dwóch systemów sterowania i obstugi krat wysypowych $\mathrm{O} / \mathrm{ZG}$ Polkowice-Sieroszowice tj. obecnego z udziałem operatora oraz zdalnego (sterowanie 2 punktami) wraz z ocena wptywu zmiany sposobu sterowania na prace całego układu przeładowczego ETAP I-III, KGHM Cuprum sp. z o.o., Wrocław 2011 [praca niepublikowana].

dr inż. LESZEK ZIĘTKOWSKI dr inż. JANUSZ MŁYNARCZYK mgr inż. WOJCIECH SOBOLEWSKI KGHM CUPRUM

Centrum Badawczo-Rozwojowe ul. gen. Władystawa Sikorskiego 2-8, 53-659 Wroctaw

\{lzietkowski, jmlynarczyk, wsobolewski\} @cuprum.wroc.pl 